\title{
Multiorganism Biofilms: A New Challenge for Ecto- and Endoprostheses
}

\section{Sammy Al-Benna* and Scott Antony Cairns}

Department of Plastic, Reconstructive and Burns Surgery, City Hospital Campus, Nottingham University Hospitals NHS Trust, Nottingham, United Kingdom

Infection may be defined as invasion by and multiplication of pathogenic microorganisms in a bodily part or tissue, which may produce subsequent tissue injury and progress to overt disease through a variety of cellular or toxic mechanisms [1,2]. However, as our understanding of infection and the behaviour of microbiota expands then we can take issue with many of the tenets in this definition.

Bacteria do not need to invade tissue in order to cause a host reaction or cause to a pathological state within a patient. The presence of bacteria within dental plaque can lead to dental caries and bacteria within a chronic wound can lead to delayed wound healing [3-6]. Similarly microorganisms which in and of themselves are not inherently pathogenic can cause disease states or predispose to infection in otherwise healthy individuals.

Using dental plaque as an example we can see it represents a multiorganism adherent population of microbiota. This is often referred to as a biofilm. A more complete definition of a biofilm would be "an adherent population of microorganisms within a polysaccharide matrix of its own creation that demonstrates increased resistance to chemical and physical attacks" [7].

The advent of electron microscopy has allowed the adherent biofilms to be identified in a many different environments from icecream factories through to healthcare related devices [8-13]. There are many aspects to the biofilm that enhance its pathogenicity. A mulitorganism biofilm, may have non-pathogenic bacteria that set-up the first crucial adherence step [14], or may even have candidal hypae within them to enhance and strengthen the polysaccharide matrix within which they reside, while candida can certainly be pathogenic, it resides within the oral cavity of $25 \%$ of the population with no obvious ill-effects [15].

It is felt that the adherence step plays a role in the recidivism of biofilm infections, and why radical surgical debridement is often cited as a cornerstone of their effective management [16,17]. One of the other aspects that make biofilms so difficult to treat is the matrix within which they reside. This matrix has demonstrated increased resistance to many antibiotics, using both physical methods of resistance, such as a negatively polarized surface of the biofilm to repel antibiotics, and chemical methods, where bacteria within the body the of the biofilm exist at different levels of metabolic activity and oxygen consumption, to render many antibiotics less effective [18-20]. This is further enhanced by the ready transmission of bacterial DNA within the biofilm allowing horizontal transfer of genetic bacterial resistance [21].

The biofilm polysaccharide matrix also provides a physical barrier against attack, such as debridement, and the action of the body's own host-defense peptides and neutrophils [22-24]. Indeed, the "fall-out" from these host defenses often results in damage to the surrounding tissues worsening existing ulceration [24-26].

While it is clear that many bacterial populations are highly developed and that biofilms represent a sophisticated phenotype with serious healthcare consequences, biofilms are not a new evolution of bacteria, and have been present since long before the discovery of penicillin [27]. Our growing understanding of this bacterial phenotype allows us to target therapies and co-ordinate management strategies in a more focused fashion. Where ecto- and endoprostheses are used in diverse areas of healthcare, practitioners need to be cognizant of bacteria biofilms and to tailor their therapy stratagems accordingly.

\section{References}

1. Al-Benna S (2012) Infection control in operating theatres. J PerioperPract 22 318-322.

2. Cairns SA, Hegarty ET (2008) Microbial load and decontamination in the theatre suite. Ann R Coll Surg Engl 90: 710.

3. Al-Benna S (2010) A discourse on the contributions of evidence-based medicine to wound care. Ostomy Wound Manage 56: 48-54.

4. Al-Benna S (2012) Construction and use of wound care guidelines: an overview. Ostomy Wound Manage 58: 37-47.

5. James GA, Swogger E, Wolcott R, Pulcini Ed, Secor P, et al. (2008) Biofilms in chronic wounds. Wound Repair Regen 16: 37-44.

6. Hill KE, Davies CE, Wilson MJ, Stephens P, Harding KG, et al. (2003) Molecular analysis of the microflora in chronic venous leg ulceration. J Med Microbiol 52 365-369.

7. Thomas JG (2008) "Advancing Your Practice: Understanding Wound Infection and the Role of Biofilms." AAWC Consensus Document 1: 2-3.

8. Gunduz GT, Tuncel G (2006) Biofilm formation in an ice cream plant. Antonie Van Leeuwenhoek 89: 329-336.

9. Al-Benna S (2011) Perioperative management of morbid obesity. J Perioper Pract 21: 225-233.

10. Al-Benna S, Al-Ajam Y, Patani N (2009) En Garde! A novel splash guard for use in wound irrigation. Ann R Coll Surg Engl 91: 83-84.

11. Loeffelbein DJ, Al-Benna S, Steinsträßer L, Satanovskij RM, Rohleder $\mathrm{NH}$, et al. (2012) Reduction of donor site morbidity of free radial forearm flaps: what level of evidence is available? Eplasty 12: e9.

12. Weisbarth RE, Gabriel MM, George M, Rappon J, Miller M, et al. (2007) Creating antimicrobial surfaces and materials for contact lenses and lens cases. Eye Contact Lens 33: 426-429.

13. Cairns S, Thomas JG, Hooper SJ, Wise MP, Frost PJ, et al. (2011) Molecular analysis of microbial communities in endotracheal tube biofilms. PLoS One 6 : e14759.

14. George S, Kishen A (2007) Effect of tissue fluids on hydrophobicity and adherence of Enterococcus faecalis to dentin. J Endod 33: 1421-1425.

15. Azoulay E, Timsit JF, Tafflet M, de Lassence A, Darmon M, (2006) Candida colonization of the respiratory tract and subsequent pseudomonas ventilatorassociated pneumonia. Chest 129:110-117.

16. Wolcott RD, Rumbaugh KP, James G, Schultz G, Phillips P, et al. (2010)

*Corresponding author: Sammy Al-Benna, Department of Plastic, Reconstructive and Burns Surgery, Nottingham University Hospitals NHS Trust, City Hospital Campus, Hucknall Road, Nottingham NG5 1PB, Nottinghamshire, United Kingdom, Tel: + (44) 115969 1169; Fax: + (44) 115962 7839; E-mail: sammyalbenna@doctors.org.uk

Received August 22, 2013; Accepted August 23, 2013; Published August 27 2013

Citation: Al-Benna S, Cairns SA (2013) Multiorganism Biofilms: A New Challenge for Ecto- and Endoprostheses. Anaplastology 2: e109. doi: 10.4172/21611173.1000 e109

Copyright: (c) 2013 Al-Benna S, et al. This is an open-access article distributed under the terms of the Creative Commons Attribution License, which permits unrestricted use, distribution, and reproduction in any medium, provided the original author and source are credited. 
Citation: Al-Benna S, Cairns SA (2013) Multiorganism Biofilms: A New Challenge for Ecto- and Endoprostheses. Anaplastology 2: e109. doi: 10.4172/2161-1173.1000e109

Page 2 of 2

Biofilm maturity studies indicate sharp debridement opens a time- dependent therapeutic window. J Wound Care 19: 320-328.

17. Al-Benna S (2010) Laundering of theatre scrubs at home. J Perioper Pract 20: 392-396

18. Mah TF, Pitts B, Pellock B, Walker GC, Stewart PS, et al. (2003) A genetic basis for Pseudomonas aeruginosa biofilm antibiotic resistance. Nature 426 : 306-310

19. Anderl JN, Franklin MJ, Stewart PS (2000) Role of antibiotic penetration limitation in Klebsiellapneumoniae biofilm resistance to ampicillin and ciprofloxacin. Antimicrob Agents Chemother 44: 1818-1824.

20. Steinstraesser L, Schubert C, Jacobsen F, Al-Benna S (2010) Editorial: glycyrrhizin against multi-resistant bacteria? J Leukoc Biol 87: 7-8.

21. Costerton JW, Montanaro L, Arciola CR (2005) Biofilm in implant infections: its production and regulation. Int J Artif Organs 28: 1062-1068.

22. Otto M (2006) Bacterial evasion of antimicrobial peptides by biofilm formation Curr Top Microbiol Immunol 306: 251-258.
23. Leid JG, Shirtliff ME, Costerton JW, Stoodley P (2002) Human leukocytes adhere to, penetrate, and respond to Staphylococcus aureus biofilms. Infect Immun 70: 6339-6345.

24. Steinstraesser L, Hauk J, Schubert C, Al-Benna S, Stricker I, et al. (2011) Suppression of soft tissue sarcoma growth by a host defense-like lytic peptide. PLoS One 6: e18321.

25. Steinstraesser L, Kraneburg UM, Hirsch T, Kesting M, Steinau HU, et al. (2009) Host defense peptides as effector molecules of the innate immune response: a sledgehammer for drug resistance? Int J Mol Sci 10: 3951-3970.

26. Steinstraesser L, Kraneburg U, Jacobsen F, Al-Benna S (2011) Host defense peptides and their antimicrobial-immunomodulatory duality. Immunobiology 216: 322-333.

27. Henrici AT (1933) Studies of Freshwater Bacteria: I. A Direct Microscopic Technique. J Bacteriol 25: 277-287. 